\title{
Editorial: XV Pan-American Conference: Selected papers on energy geotechnics
}

1 Guillermo A. Narsilio PhD, MSc(Math), MSc(CE), CEng Department of Infrastructure Engineering, The University of Melbourne, Parkville, Australia (corresponding author: narsilio@unimelb.edu.au)

2 Marcelo Sánchez PhD, MSc(CE), CEng

Zachry Department of Civil Engineering, Texas A\&M University, College Station, TX, USA
3 Jose Alvarellos PhD, MSc(CE), CEng

Repsol, S.A., Repsol Technology Centre, Carretera de Extremadura, Mostoles, Spain

4 Leonardo Guimarães $\mathrm{PhD}, \mathrm{MSc}(\mathrm{CE}), \mathrm{CEng}$

Department of Civil Engineering, Federal University of Pernambuco, Recife, Brazil
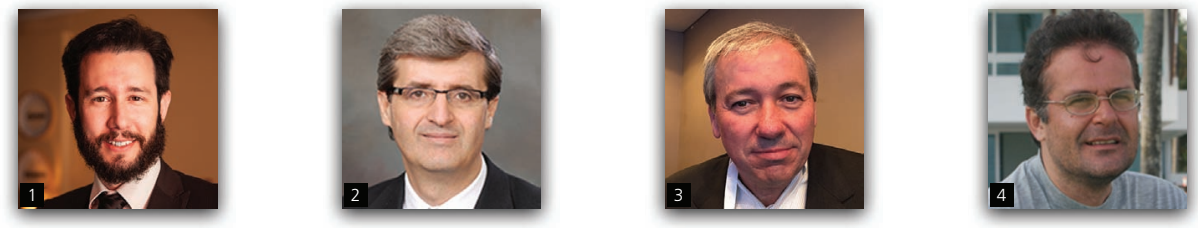

\section{Introduction: The XV Pan-American Conference}

This themed issue of Environmental Geotechnics, XV PanAmerican Conference: Selected papers on energy geotechnics, presents some of the papers of the XV Pan-American Conference on Soil Mechanics and Geotechnical Engineering (XV PCSMGE) that are of particular interest to readers in the emerging energy geotechnics topic and that were highly ranked by the conference paper reviewers. PCSMGE is the largest regional conference of the International Society for Soil Mechanics and Geotechnical Engineering (ISSMGE), involving two regions of the ISSMGE, and is held every 4 years.

The first PCSMGE was held in Mexico City, Mexico, 7-12 September 1959. It was convened by an ad hoc committee under Enrique Tamez, Secretary. The 15th, and latest, PCSMGE was held in Buenos Aires, Argentina, 15-18 November 2015, 40 years after Argentina hosted its first Pan-American conference in 1975. The XV PCSMGE coincided with three important events for geoprofessionals: the VIII South American Conference on Rock Mechanics (VIII CSMR), the 6th International Symposium of Deformation Characteristics of Soils (IC-BA2015) and the XXII Argentinian Congress of Soil Mechanics and Geotechnical Engineering (CAMSIG XXII).

This event brought together about a thousand people not only from the Americas but from around the world, including international experts, researchers, academics, professionals and geoengineering companies, who exchanged ideas and discussed current and future practices in the areas of soil mechanics, rock mechanics and their applications in civil, mining, petroleum and environmental engineering.

The main topics of the XV PCSMGE conference were

- transportation geotechnics

- in situ testing
- geoengineering for energy and sustainability

- numerical modelling in geotechnics

- foundations and ground improvement

- unsaturated soils

- embankments, dams and tailings

- excavations and tunnels

georisks.

During the conference, a total of 19 keynote speakers (including three plenary lecturers), seven invited speakers, and 25 panellists from local and global Industry and academia provided a review of topics and innovation, which are of interest to the geocommunity, under the conference theme 'From fundamentals to applications in geotechnics'. In addition, a total of 435 peer-reviewed technical papers were presented and discussed in oral, 'agora' (i.e. interactive poster) and poster presentations. Through these interactions, advanced knowledge and ideas were interchanged, allowing crossfertilisation and promotion of a true community of colleagues in geotechnical and geoenvironmental engineering. These conference papers have been compiled as digital and printed proceedings (Manzanal and Sfriso, 2015).

The authors of the highest ranked papers in the third conference stream, 'Geo-engineering for energy and sustainability', were invited to resubmit an extended version for this issue of Environmental Geotechnics. These papers are of particular relevance to the members of the ISSMGE Technical Committee 308, Energy Geotechnics, and the readership of the journal interested in sustainable development and energy derived from the ground.

\section{Contributions to this issue: energy geotechnics at the XV PCSMGE}

In the last few years, geotechnical/geoenvironmental engineering has shaped a new research area, energy geotechnics, in an effort to respond to the increasing demand of energy associated with 
Table 1. Energy resources and associated geotechnics involvement (modified from Santamarina and Cho, 2011)

\begin{tabular}{|c|c|c|c|c|c|c|c|}
\hline \multicolumn{3}{|c|}{ Non-renewable (fossil fuels) } & \multicolumn{4}{|c|}{ Renewable } & \multirow{2}{*}{ Nuclear } \\
\hline Coal & Gas & Petroleum & Solar & Geothermal & Wind & Biofuels & \\
\hline $\begin{array}{l}\text { Characterisation, } \\
\text { subsurface } \\
\text { response, mine } \\
\text { excavation and } \\
\text { instability, and gas } \\
\text { recovery }\end{array}$ & $\begin{array}{l}\text { Hydrates, low- } \\
\text { temperature } \\
\text { liquefied natural } \\
\text { gas storage, } \\
\text { hydraulic fracturing, } \\
\text { and optimal } \\
\text { extraction }\end{array}$ & $\begin{array}{l}\text { Fines and clogging, } \\
\text { sand production, } \\
\text { borehole instability, } \\
\text { enhanced oil } \\
\text { recovery, heavy oil } \\
\text { and tar sand }\end{array}$ & - & $\begin{array}{l}\text { Drilling, fracture } \\
\text { formation, } \\
\text { heat transfer, } \\
\text { piles and } \\
\text { optimisation }\end{array}$ & $\begin{array}{l}\text { Off-/on-shore } \\
\text { foundations and } \\
\text { pseudodynamic } \\
\text { loading }\end{array}$ & $\begin{array}{l}\text { Land and water } \\
\text { use, energy } \\
\text { efficiency, } \\
\text { and food } \\
\text { impact }\end{array}$ & $\begin{array}{l}\text { Engineered soils, } \\
\text { decommission, } \\
\text { leak detect and } \\
\text { repair, and long- } \\
\text { term behaviour } \\
\text { and monitoring }\end{array}$ \\
\hline
\end{tabular}

economic development and population growth (Ghaaowd et al., 2017; Sánchez et al., 2017). Indeed, since the industrial revolution, the human population growth and the annual per capita energy consumption have increased exponentially (Glassley, 2010).

Mitigating the environmental impacts of an ever-growing population has become inextricably linked to find renewable and more sustainable energy sources (Arulrajah et al., 2015). Table 1 presents a comprehensive overview of all energy resources, including fossil fuels, renewable and nuclear sources, together with some of the issues where geotechnical engineering expertise is needed (Santamarina and Cho, 2011). Indeed, there are a number of geotechnical needs in the growing renewable energy sector as well as in the non-conventional fossil fuel exploitation, which have been summarised elsewhere (Sánchez et al., 2017; Yun et al., 2011). The paper by Sánchez et al. (2017) presents the main discussions and comments associated with the expert panel on 'Geo-engineering for energy', ranging from oil and gas exploitation to carbon geosequestration and energy efficient technologies.

It is generally agreed that a combination of measures is needed to reduce greenhouse gas emissions, including the use of alternative, renewable and sustainable energy sources and of more energy efficient technologies. Here, heat transfer and fluid flow in geomaterials and their influence on the geomechanical behaviour of soils and rocks play critical roles. The estimation of thermal parameters of geomaterials becomes then, important, and new ways of estimating such parameters are needed (Hailemariam et al., 2017). These parameters are of the upmost importance in engineering design and predictive modelling: the fundamental understanding of the influences of heated soils on the development of excess pore water pressures in thermal storage technologies (Ghaaowd et al., 2017) and/or in the long-term prediction of geomaterial behaviour in nuclear repositories (Jacinto and Ledesma, 2017) are some examples of the contributions made by the geo-community to energy geotechnics.

One of the engineering applications concerning ground thermomechanical response involves the use of ground source heat pumps or shallow geothermal technology (Sánchez et al., 2017), which can be used even under extreme climate conditions, for example to control frost heave and the thaw settlement of frozen ground beneath an ice rink facility in Helsinki (Iceland) (Sinnathamby et al., 2017).
This issue of Environmental Geotechnics also deals with other emerging technologies, some in the pathways to commercialisation, such as new cleaner coal technologies using underground coal gasification (Sarhosis et al., 2017) or coalbed methane recovery, which also enables carbon sequestration (Lee et al., 2017); and exploitation of methane gas hydrates and the required modelling of the mechanical response of their host sediments (Gai and Sanchez, 2017).

Advanced geotechnical and geoenvironmental techniques, including advanced laboratory and in situ testing and numerical modelling methods, continue to develop at a rapid pace, as demonstrated by the papers in this issue, which captures just a snapshot of the diversity and importance of energy geotechnics within our disciplines.

\section{Acknowledgements}

We are grateful to Environmental Geotechnics for undertaking this snapshot of XV PCSMGE 2015, and to all authors for their contributions to this special issue. We are indebted to the Argentine Geotechnical Society (SAIG in Spanish - Sociedad Argentina de Ingeniería Geotécnica) and sponsors and contributors of the conference for their support. Any opinions, findings, conclusions, or recommendations expressed herein are those of the authors alone and do not necessarily reflect the views of ISSMGE or SAIG.

\section{REFERENCES}

Arulrajah A, Narsilio G, Kodikara J and Orense RP (2015) Key issues in environmental geotechnics: Australia-New Zealand. Environmental Geotechnics 2(6): 326-330, http://dx.doi.org/10.1680/ envgeo.14.00005.

Gai X and Sánchez M (2017) Mechanical modelling of gas hydrate bearing sediments. Environmental Geotechnics 4(2): 143-156, http://dx.doi. org/10.1680/jenge.15.00050

Ghaaowd I, Takai A, Katsumi T and McCartney JS (2017) Pore water pressure prediction for undrained heating of soils. Environmental Geotechnics 4(2): 70-78, http://dx.doi.org/10.1680/jenge.15.00041.

Glassley W (2010) Geothermal Energy: Renewable Energy and the Environment. CRC Press, Boca Raton, FL, USA.

Hailemariam H, Shrestha D, Wuttke F and Wagner N (2017) Thermal and dielectric behaviour of fine-grained soils. Environmental Geotechnics 4(2): 79-93, http://dx.doi.org/10.1680/jenge.15.00042.

Jacinto AC and Ledesma A (2017) Thermo-hydro-mechanical analysis of a full-scale heating test. Environmental Geotechnics 4(2): 123-134, http://dx.doi.org/10.1680/jenge.15.00049.

Lee G-J, Choi S-K and Kwon T-H (2017) Hydromechanical responses of coal powders by $\mathrm{CO}_{2}$ adsorption. Environmental Geotechnics 4(2): 94-102, http://dx.doi.org/10.1680/jenge.15.00048. 
Manzanal D and Sfriso A (eds) (2015) From fundamentals to applications in geotechnics. Proceedings of the 15th Panamerican Conference on Soil Mechanics and Geotechnical Engineering, Buenos Aires, Argentina. IOS Press, Amsterdam, the Netherlands, vol. 3, http://www. iospress.nl/book/from-fundamentals-to-applications-in-geotechnics/.

McCartney JS, Sánchez M and Tomac I (2016) Energy geotechnics: advances in subsurface energy recovery, storage, exchange, and waste management. Computers and Geotechnics 75: 244-256, http://dx.doi. org/10.1016/j.compgeo.2016.01.002.

Sánchez M, Falcão F, Mack M, Pereira J-M, Narsilio GA and

Guimarães L (2017) Salient comments from an expert panel on energy geotechnics. Environmental Geotechnics 4(2): 135-142, http://dx.doi. org/10.1680/jenge.16.00008.
Santamarina JC and Cho GC (2011) Energy geotechnology. KSCE Journal of Civil Engineering 15(4): 607-610.

Sarhosis V, Lavis S, Mostade M and Thomas HR (2016) Towards commercialising underground coal gasification in the EU. Environmental Geotechnics 4(2): 113-122, http://dx.doi.org/10.1680/ jenge. 15.00044 .

Sinnathamby G, Gustavsson H, Korkiala-Tanttu L, Cervera PC and Koskinen M (2017) Case study: frost heave and thaw settlement under an ice rink. Environmental Geotechnics 4(2): 103-112, http://dx.doi. org/10.1680/jenge.15.00047.

Yun TS, Lee JS, Lee SC, Kim YJ and Yoon HK (2011) Geotechnical issues related to renewable energy. KSCE Journal of Civil Engineering 15(4): 635-642. 